\title{
Tantangan Guru dan Masalah Sosial Di Era Digital
}

\author{
Abdul Latif \\ Universitas Hamzanwadi \\ Email : $\underline{\text { latif17sosiologi@gmail.com }}$
}

\begin{abstract}
Abstrak. Peran guru dalam pembelajaran era digital ada tujuh yakni: (a) guru sebagai sumber belajar; peran guru sebagai sumber belajar berkaitan dengan kemampuan guru dalam menguasai materi pelajaran. (b) guru sebagai fasilitator; peran guru sebagai fasilitator dalam memberikan pelayanan kepada siswa untuk dapat memudahkan siswa menerima materi pelajaran. (c) guru sebagai pengelola; dalam proses pembelajaran, guru berperan untuk memegang kendali penuh atas iklim dalam suasana pembelajaran; (d) guru sebagai demonstrator; berperan sebagai demonstrator maksudnya disini bukanlah turun ke jalan untuk berdemo. Guru itu sebagai sosok yang berperan untuk menunjukkan sikap-sikap yang akan menginspirasi siswa untuk melakukan hal yang sama, bahkan lebih baik; (e) guru sebagai pembimbing; perannya sebagai seorang pembimbing, guru diminta untuk dapat mengarahkan kepada siswa untuk menjadi seperti yang diinginkannya; (f) guru sebagai motivator; proses pembelajaran akan berhasil jika siswa memiliki motivasi didalam dirinya; (g) guru sebagai elevator; guru haruslah mengevaluasi semua hasil yang telah dilakukan selama proses pembelajaran.Tantangan guru di era digital; guru sampai sekarang masih banyak memakai produk 80an, sementara muridnya sudah memakai produk kontemporer. Akibatnya, para murid berbeda secara radikal dengan para guru, karena banyak terjadi ketidaknyambungan di sana-sini. Kita tahu bahwa murid sekarang tidak lagi cocok dengan sistem pendidikan abad 20. Namun, praksis di lapangan para guru masih tidak memahami hal ini. Banyak guru kita yang lambat mengejar laju modernisasi pendidikan. Yang terjadi kemudian adalah murid sudah mampu menerima informasi secara cepat dari berbagai sumber multimedia, sementara banyak guru acapkali memberikan informasi dengan lambat dan dari sumber-sumber terbatas.
\end{abstract}

\section{Kata kunci: Guru, Masalah Sosial, Era Digital}

\section{PENDAHULUAN}

Kenyataan masih memprihatinkan yang terjadi pada dunia pendidikan kita adalah kemajuan zaman tidak berbanding lurus dengan kemajuan guru. Kita pun masih menyaksikan realitas yang kontras antara guru dan murid. Murid sudah sedemikian maju dalam iklim digital, sementara guru masih berkutat pada tradisi tekstual. Guru sekarang masih banyak memakai produk 80-an, sementara muridnya sudah memakai produk kontemporer. Akibatnya, para murid berbeda secara radikal dengan para guru, karena banyak terjadi ketidaknyambungan di sana-sini.

Pendidikan merupakan sarana untuk meningkatakan Sumber Daya Manusia (SDM), untuk itu segala persoalan harus dijawab, baik berupa perangkat kurikulum yang sering Jurnal Ilmu Sosial dan Pendidikan mengalami perubahan sampai kepada peningkatan kualitas seorang pendidik. Peningkatan kualitas manusia telah dicoba di dunia melalui proses pendidikan, karena pendidikanlah yang membuat kesejahteraan masyarakat akan tercapai. Pendidikan sebagai bagian dari kebudayaan merupakan wadah untuk mencerdaskan kehidupan bangsa, mengembangkan masyarakat dengan berbagai dimensinya, serta pengembangan nilai-nilai, norma-norma, pengetahuan, keterampilan, dan sikap peserta didik.

Anthony Giddens (1990) menyebutkan sebagai gelobalisasi dini, yaitu intesifikasi relasi-relasi social dunia yang menghubungkan lokalitas yang berjauhan sedemikian rupa sehingga peristiwa-peristiwa local dipengaruhi 
oleh peristiwa yang terjadi jauh di seberang dan begitu pun sebaliknya.

Perkembangan teknologi informasi dan komunikasi sangat cepat dalam satu dasa warsa terakhir ini. Perkembangan ini dipastikan menyentuh, bahkan melahirkan orientasi baru pada semua bidang kehidupan manusia, baik sosial, budaya, ekonomi, politik, hukum, maupun pendidikan. Telah terjadi pergeseran dari era pengetahuan, ke era informasi dan komunikasi. Transisi dari komunitas berbasis pengetahuan ke komunitas berbasis informasi dan komunikasi membawa perubahan yang dramatis, terutama dalam hal, bagaimana informasi dikonstruksi menjadi pengetahuan yang dapat dikomunikasikan dengan cepat dan secara luas kepada semua warga negara, sehingga tidak ada warga negara yang terisolasi dalam informasi.

Menjadi guru di abad 21 berbeda dengan guru di abad 20-an. Di era digital seperti sekarang ini, eksistensi guru tidak lagi dilihat dari kharismanya semata. Karim dan Saleh Sugiyanto (2006). Lebih dari itu, bagaimana seorang guru mampu berkomunikasi dan beradaptasi mengikuti arah tangan zaman. Guru di era digital dituntut mampu berinovasi dan berkreasi, karena sistem pembelajaran tahun 80-an sudah tidak diterima oleh anak didik zaman sekarang.

Tapscott, (1997) akibat perkembangan teknologi internet dan kemajuan teknologi digital yang telah terakselerasi , informasi, dan pengetahuan menjadi bersifat sementara dan singkat. Pengetahuan yang bersifat sementara membutuhkan pembaharuan secara konstan, perkembangan dan peningkatan kemampuan pribadi. Kemajuan ini mempengaruhi dunia pendidikan secara mendasar, dari cara pandang terhadap pengetahuan, sampai dengan bagaimana pengetahuan itu diajarkan di depan kelas. Hal ini juga tentu berpengaruh terhadap dunia pendidikan guru dan tenaga kependidikan, terutama bagaimana kompetensi guru harus diorientasikan terhadap perkembangan Jurnal Ilmu Sosial dan Pendidikan teknologi informasi dan komunikasi dan masyarakat digital dewasa ini.

Bastian, Aulia Reza. (2002) lebih lanjut, perubahan tempat belajar, yakni transisi dari era analog ke era digital, juga dianggap penting. Di era digital, lingkungan belajar harus diselaraskan dengan pemanfaatan teknologi informasi dan komunikasi, misalnya internet dan cybernet, yang memungkinkan pemelajar belajar secara mandiri, dinamis dan tidak terikat oleh hanya satu tempat dan satu sumber belajar, bahkan tidak tergantung pada guru pengajarnya saja, tetapi siswa dapat belajar dari banyak guru, berbagai sumber di dunia maya.

Oleh karena itu, semua elemen kompetensi guru yang cenderung memperlakukan

siswa hanya berdasarkan pengalaman, kemampuan, pengetahuan dan sumber-sumber belajar yang dimiliki seorang guru, atau singkatnya mengukur potensi dan kemampuan siswa hanya dengan otak seorang guru yang bersangkutan tidak relevan lagi (bandingkan dengan Depdikbud, 2003). Tetapi dalam era digital dinamis ini guru harus menerapkan konsep multy channel learning yang memperlakukan siswa sebagai pemelajar dinamis yang dapat belajar dimana saja, kapan saja, dari siapa saja, dari berbagai sumber di mana saja. Dalam hal ini guru hendaknya bertindak sebagai fasilitator yang menunjukkan kompetensi yang harus dimiliki oleh siswa, dan membuka kesempatan pada siswa untuk dapat belajar dari berbagai sumber pembelajaran digital di dunia global.

Kemajuan dalam belajar dapat disesuaikan dengan kebutuhan tergantung pada ketersediaan akses pengetahuan dan informasi, yang kini dapat diperoleh dengan mudah dan cepat, yaitu dalam hitungan mouse click. Orientasi baru ini akan memberikan pengaruh positif terhadap kemajuan kreativitas dan daya imajinasi pemelajar. Selain itu, kemampuan berpikir kritis dan analitis pemelajar diharapkan dapat ditingkatkan, misalnya dengan mengasah kemampuan 
mereka untuk menemukan dan mengidentifikasiberbagai hal secara cepat di dunia maya. Semua ini akhirnya diharapkan dapat meningkatkan daya saing pemelajar itu sendiri. Selanjutnya akan dibahas mengenai beberapa reorientasi baru pembelajaran yang dianggap mempengaruhi visi, tanggung jawab, sensitivitas sosial dan kemampuan logika, serta kejujuran guru. Semua ini bermuara pada reorientasi pada peran baru guru, yaitu sebagai agen perubahan, pembaharuan pengetahuan dan konsultan pembelajaran.

\section{PEMBAHASAN}

Peran guru dalam pembelajaran yang memusatkan pada konstruksi, pencarian dan penemuan; dahulu pendidikan diartikan sebagai sesuatu yang bersifat satu arah, yang menuntut penyampaian informasi oleh seorang ahli dan pemerolehan pengetahuan yang telah disiapkan, oleh siswa. Dalam hal ini, seorang guru dianggap sebagai ahli yang mempunyai jawaban untuk setiap pertanyaan, sehingga ia memiliki otoritas penuh. Di sisi lain, para siswa selalu dianggap sebagai pelajar pasif, penerima apapun yang diajar oleh guru. Bennett (1993), pada era TIK digital ini dibutuhkan sebuah orientasi baru dalam pendidikan yang menekankan pada konstruksi aktif siswa melalui pencarian berbagai macam informasi serta sumber-sumber lainnya yang berguna untuk kehidupan mereka dalam berbagai situasi. Orientasi baru ini memfokuskan pada kegiatan pembelajaran yang menuntut motivasi diri siswa (self-motivated) dan pengaturan diri sendiri (self-regulated). Hal ini diperlukan dalam rangka konstruksi pengetahuan dan pengalaman yang bisa diterapkan dalam konteks-konteks tertentu yang dihadapi siswa. Untuk memperoleh pengetahuan ini dibutuhkan partisipasi aktif dalam perkembangan pribadi melalui pendidikan interaktif dan aplikasinya, bukan semata dengan "menyerap" secara pasif pengetahuan yang telah dirancang oleh orang lain.

Jurnal Ilmu Sosial dan Pendidikan
Peran guru dalam pembelajaran yang menekankan pada kreativitas dan inisiatif; pendidikan konvensional cenderung menampilkan kemampuan manual individu yang mampu menyelesaikan tugas yang diberikan. Pemelajar yang mengikuti kebiasaan dan jalur-jalur yang ditentukan, menggunakan sumber-sumber yang disediakan oleh guru secara efektif, serta berada pada batas-batas yang telah dirancang, dianggap mencapai hasil terbaik dalam metodologi ini.

Buchori, Mochtar (1995) bagi yang mencari hal-hal baru dengan berbagai pilihan tidak diuntungkan dalam hal ini. Kenyataan ini sering ditemukan dan erat hubungannya dengan lingkungan sosial yang telah struktur secara keras dan kaku. Hal ini tentu saja, tidak sesuai dengan lingkungan global saat ini, yaitu lingkungan dengan perkembangan yang pesat dan cepat, lingkungan dengan tantangan yang penuh dengan hal-hal yang tidak terduga dan melibatkan banyak hal dalam jangkauan yang luas. Apa yang diperlukan dalam konteks ini adalah orang-orang dengan kompetensi tingkat tinggi, yaitu orang kreatif, penuh inisiatif dan intensif untuk memberikan solusi inovatif terhadap tantangan yang semakin kompleks memenuhi kebutuhan dan harapan individu siswa, misalnya melalui interaksi terencana di antara siswa dengan komputer, belum memenuhi tuntutan dalam lingkungan belajar era digital global dewasa ini. Model pembelajaran yang digunakan cenderung belum berhasil menciptakan interaksi yang dinamis, baik kerjasama antar siswa, siswa dengan guru, maupun siswa dengan berbagai sumber pembelajaran. Lim, Cher-Ping and Tay, Lee-Yong (2006) pembelajaran yang bersifat interaktif dan kolaboratif diharapkan mampu memperkaya pengalaman belajar dengan menyediakan kesempatan bagi siswa untuk belajar melalui pemberian masalah yang nyata dengan beragam sudut pandang dari berbagai aspek, dan yang terpenting adalah pengalaman berbagi dan hidup bersama dalam masyarakat. 
Ketiga peran baru dalam pembelajaran tersebut dapat dijadikan landasan untuk melakukan kajian terhadap visi, tanggung jawab, sensitivitas sosial, kemampuan logis dan kejujuran guru dalam masyarakat digital global dewasa ini. Berikut akan disarikan beberapa pemikiran ke arah itu, yaitu:

1. Visi guru; paradigma dalam pendidikan saat ini telah beralih dari paradigma mengajar menuju paradigma belajar. Ini berarti bahwa pendidikan bukan lagi mengenai bagaimana menyampaikan pengetahuan dan informasi kepada siswa, tetapi tentang bagaimana membantu siswa untuk mencari danmenemukan (search-discovery) informasi sendiri dan kemudian membantu siswa untuk mengkonstruksi dan menciptakan (construction-invention) pengetahuan yang bermanfaat bagi diri mereka. Guru tidak lagi bertanggung jawab atas pengetahuan yang disimpan dalam pikiran para siswa, tetapi bagaimana siswa mampu membangun pengetahuan secara mandiri (Geddis, 1993). Hal ini bukan berarti guru adalah pembantu yang pasif, tetapi aktif dalam proses konstruksi tersebut, misalnya melalui penciptaan lingkungan belajar yang berpegang pada prinsip multy channel learning. Dalam era digital global dewasa ini, hal ini hendaknya menjadi visi yang jelas bagi guru, bagaimana memperlakukan siswa dalam belajar;

2. Tanggung jawab moral guru; pekerjaan utama guru tentu saja mengajar. Dalam lingkup sosial, guru juga memiliki tanggung jawab dalam membangun konsep diri siswa, misalnya tentang moralitas dan keanekaragaman etnik. Hal ini dapat diberikan melalui persentasi norma-norma sosial dan hal-hal yang dilarang, baik secara langsung melalui aspek-aspek pendidikan yang diajarkan, atau secara tidak langsung melalui contoh-contoh penerapan. Perkembangan teknologi informasi dan komunikasi yang pesat serta tingginya tingkat keambiguan dalam teknologi memberi peluang terjadinya berbagai masalah, misalnya cara interaksi sosial yang tindakan maupun pada tingkah laku yang menyimpang. Salah satu sebab adalah peningkatan isolasi bagi mereka yang berinteraksi secara berlebihan pada internet dan sebagai konsekuensinya dapat menurunkan interaksi antar individu. Lebih lanjut, kemungkinan konsekuensi negatif mengenai ketertutupan dan pemisahan diri yang diakibatkan oleh akses global, mengakibatkan melemahnya norma-norma sosial. Hal-hal selebihnya harus didiskusikan atau setidaknya disadari yaitu kondisi dalam dunia pendidikan dimana interaksi banyak berpusat pada teknologi informasi dan komunikasi;

3. Sensitivitas sosial guru; dalam komunitas berbasis pengetahuan digital, terjadi penekanan pada nilai-nilai finansial serta nilai-nilai ekonomis pada pengetahuan. Sebagai contoh, di negara maju dimana komunitas digital berkembang sangat pesat, telah disinyalir penurunan sensitivitas kemanusiaan dalam mata kuliah di kampus, terutama pada ilmu-ilmu/ jurusan-jurusan sains yang berat. Hal ini tidak begitu terjadi pada ilmu yang difokuskan pada penerapan dalam kehidupan sehari-hari. Hal yang tidak boleh dilupakan dalam mengembangkan originalitas dan imajinasi, yakni seseorang harus menanamkan rasa kemanusiaan dan sensitivitas sosial. Penerapan TIK digital dalam dunia pendidikan tidak boleh mengurangi hal ini. Hal ini merupakan tantangan tersendiri bagi guru dalam dunia digital global dewasa ini. Untuk itu, guru perlu menjadi orang yang literat dalam halhal digital sehingga mampu memahami serta siap dengan lingkungan berteknologi tinggi yang mengelilingi mereka, serta yang akan menjadi hal yang mereka sentuh langsung dalam dunia kerjanya. Literasi digital guru tidak hanya berarti kemampuan untuk menumpulkan, memilih, memperbaiki dan memproses informasi, 
tetapi juga untuk menilai dan menentukan kredibilitas informasi. Dalam hal tertentu hasil perbaikan dan pemprosesan dapat berbeda satu sama lainnya tergantung sensitivitas sosial guru tersebut. Oleh sebab itu komunitas digital memerlukan guru yang memang literat, secara digital, dan juga sensitif, secara sosial. Sensitivitas sosial dalam hal ini adalah kemampuan untuk

memperoleh pengetahuan budaya, serta sensitivitas untuk bekerja dengan sukses dalam bidang pendidikan yang berubah sangat cepat;

4. Reorientasi kemampuan logika dan kejujuran guru; guru harus memiliki kemampuan untuk memberikan alasanalasan secara logis dalam bidang ilmu yang diajarkan, dengan cara membangun keahlian, dan memperbaharuinya sesuai dengan perkembangan terbaru secara berkesinambungan. Sebagai tambahan, guru harus memiliki kemampuan untuk menggunakan contoh-contoh nyata yang berkaitan dengan kehidupan siswa dan menghubungkan dengan mata pelajaran yang diajarkan. Guru harus tanggap untuk tidak membuat siswanya merasa bosan dengan hanya menyampaikan materi pelajaran secara searah seperti yang telah direncanakan. Tetapi guru harus meningkatkan kreativitas tentang bagaimana siswa belajar mengkonstruksi pengetahuan, misalnya bagaimana menciptakan lingkungan belajar yang memungkinkan siswa belajar secara aktif dan mandiri dari berbagai sumber pembelajaran, yang memungkinkan siswa membangun kompetensi mereka secara utuh, dari kompetensi dasar sampai kompetensi tingkat tinggi (Sudiarta, 2007). Di samping itu, di tengah tumpah ruahnya informasi dan sumber belajar digital yang dapat diakses secara cepat dan luas, guru harus mampu menjadi pelopor kejujuran dalam belajar, misalnya jujur dengan menunjukkan sumber bahan ajar digital yang digunakan, jujur bahwa dia belum mengakses informasi digital tertentu yang dibutuhkan, dan sebagainya. Berdasarkan keempat butir dalam masyarakat digital global tersebut dapat diturunkan konsekuensi logis terhadap peran guru dalam masyarakat digital global dewasa ini. Dalam hal ini guru dapat memiliki paling tidak tiga peran penting dalam pendidikan berbasis digital global, yaitu sebagai pembawa perubahan, pembaharu pengetahuan, serta konsultan pembelajaran sebagai berikut. (1) pembawa perubahan; perubahan adalah hal yang kekal dalam kehidupan. Manajemen perubahan tidak hanya berarti respon pasif pada perubahan tersebut tetapi juga bagaimana seseorang dapat secara aktif dan intensif merencanakan perubahan. Lehtinen (2006), dalam konteks ini peran guru harus beranjak dari 'penyedia jawaban', yaitu seseorang yang memproses dan menyajikan pengetahuan yang diperlukan dalam menghadapi perubahan, menjadi 'pembawa perubahan' yaitu orang yang membantu siswa dalam menemukan pengetahuan yang diperlukan untuk menghadapi perubahan, serta membantu mereka agar mampu secara aktif mengatur strategi perkembangan pribadi. Dengan kata lain, peran guru dalam era pengetahuan digital, yaitu mengatasi potensi keterkejutan akan perubahan, membantu siswa memulai visi baru untuk masa depan, memotivasi kepemimpinan bagi mereka agar mampu membantu dirinya dalam memulai perannya masing-masing, serta membantu mereka agar mampu melanjutkan program pengembangan diri. (2) pembaharu pengetahuan, perkembangan informasi telah banyak didesentralisasi sejak era perkembangan komputer. Makin pesatnya teknologi jaringan digital diikuti 'prinsip keterbukaan informasi' memungkinkan orang-orang untuk bertukar informasi dan berbagi banyak sumber/ berbagai sumber (information exchange and resource sharing) 
Tantangan guru di era digital; guru sampai sekarang masih banyak memakai produk 80-an, sementara muridnya sudah memakai produk kontemporer. Akibatnya, para murid berbeda secara radikal dengan para guru, karena banyak terjadi ketidaknyambungan di sana-sini. Kita tahu bahwa murid sekarang tidak lagi cocok dengan sistem pendidikan abad 20. Namun, praksis di lapangan, para guru masih tidak memahami hal ini. Banyak guru kita yang lambat sekali mengejar laju modernisasi pendidikan. Yang terjadi kemudian adalah murid sudah mampu menerima informasi secara cepat dari berbagai sumber multimedia, sementara banyak guru acapkali memberikan informasi dengan lambat dan dari sumber-sumber terbatas. Para murid suka melihat gambar, mendengarkan musik dan melihat vidio terlebih dahulu sebelum melihat teksnya, sementara guru memberikan teks terlebih dahulu. Para murid suka melakukan kegiatan kebersamaan sekaligus, seperti menyelesaikan tugas sambil mendengarkan musik dari laptop, sementara guru cenderung menghendaki untuk melakukan satu hal saja pada satu waktu.

Murid ingin mengakses nformasimultimedia hyperlink secara acak, sedangkan guru lebih suka menyediakan informasi secara linear, logis dan lempang. Murid menyukai interaksi simultan dengan banyak orang, sementara guru menginginkan muridnya bekerja secara independent. Murid menyukai pelajaran yang relevan, menarik dan dapat langsung digunakan (instan), gurunya ingin mengikuti kurikulum dan memenuhi standarisasi. Fenomena ini seolah menjadi pil pahit yang harus kita telan bersama. Geliat dunia virtual yang dewasa ini lebih digandrungi oleh anak didik kita menjadikan guru harus berpikir ulang untuk menata sistem mengajar yang relevan, inovatif dan adaptif.

Kita cermati di masyarakat atau sekolah, murid sekarang selain mengikuti materi secara face to face terhadap guru di sekolahan, mereka juga memiliki guru yang luar biasa Jurnal Ilmu Sosial dan Pendidikan ampuh di ruang virtual, yaitu "Google". Mesin pencari Google ini mampu memfasilitasi pencarian ilmu pengetahuan dengan sangat cepat dan praktis. Google yang diciptakan oleh Larry Page dan Sergey Brin pada tahun 1995 seolah membalikkan sekat keterbatasan informasi. Para siswa dapat menggali informasi apa saja dari seluruh belahan dunia tanpa harus bercapek-capek. Cukup duduk manis, "klik", dalam hitungan detik akan muncul apa yang diinginkan

Apalagi fenomena jejaring sosial seperti facebook dan twitter. Jejaring sosial yang sedang marak digandrungi masyarakat ini juga berpotensi besar menggeser peran guru sebagai seorang pendidik yang salah satu fungsinya adalah menyebarkan informasi dan ilmu pengetahuan. Betapa tidak, melalui dunia virtual, siswa mampu dengan mudah bergaul, berkonsultasi, bertegur dan bersapa ria, dan menggali relasi dari siapa saja lewat layanan catting yang tersedia.

Oleh karena itu, kondisi riil abad 21 ini akan menjadi tantangan atau bahkan ancaman tersendiri bagi guru. Sebab, guru yang datang dari dunia pra-digital akan sangat kualahan menghadapi murid era digital. Kenyataan yang terjadi guru akan menemui kesulitan dalam membangun komunikasi yang efektif dengan anak-anak. Karena kebiasaan dan cara belajar mereka sering berbeda. Hal inilah yang acapkali membuat kedua belah pihak, murid di satu pihak dan guru di lain pihak, sama-sama frustrasi.

Strategi mengatasi tantangan; sistem pendidikan yang masih terjebak pada otoritas struktural-birokratis harus segera dibenahi. Daya kreasi dan inovasi seorang guru harus segera dimunculkan. Guru era digital tidak boleh mengikuti kurikulum yang baku dan kaku. Sebab, kenyataan dari banyaknya sistem pembelajaran yang berlangsung, guru masih berkutat pada apa-apa yang tengah dicetuskan oleh pemerintah, di mana ketika guru mengajar hanya terpaku pada target kurikulum yang kaku dan mekanistis. Dengan demikian, banyak kita temukan tipe-tipe guru 
kurikulum, yakni guru yang melihat tolok ukur keberhasilan dipusatkan pada angka kuantitatif yang diperoleh dalam evaluasi saja.

Fenomena ini tentu memberikan pengertian bahwa eksistensi guru dari satu sisi akan mengalami ancaman, karena guru akan kehilangan pekerjaan dan ditinggalkan muridnya. Namun disisi lain, guru justru banyak sekali mendapat peluang apabila mampu meningkatkan profesionalitas dan kapabilitasnya.

Paradigma baru dalam pembangunan pendidikan di Indonesia, misalnya melalui jaringan INHERENT (Indonesia Higher Education Network) oleh DIKTI, dan Jardiknas oleh Depdiknas (Sudiarta, 2007). Hal ini telah menggantikan prinsip ketertutupan informasi yang berada di bawah kuasa tangan orang-orang tertentu. Kreasi pengetahuan oleh beberapa orang kreatif telah pada puncaknya dan harus memberikan jalan pada pengetahuan itu sendiri untuk dibagi oleh orang-orang dalam jaringan, sehingga mereka mampu untuk berbagi ide berdasarkan kreativitas dan imajinasi mereka sendiri.

Dalam lingkungan perubahan ini peran guru seharusnya tidak bersifat parsial pada kantong jaringan ilmu yang berisi ilmu-ilmu yang diproses atau 'otak super' yang berfungsi sebagai sumber ilmu pengetahuan; tetapi lebih pada pembaharu pengetahuan yang menyediakan navigasi atau pengarah pada sumber-sumber pengetahuan yang berguna.

Oleh sebab itu dalam komunitas digital guru hendaknya tidak mengajarkan pengetahuan secara terpisah, tetapi mengajarkan metode penemuan dimana dan dengan cara seperti apa informasi dan sumbersumber dapat diperoleh, serta mengajarkan caracara memproses pengetahuan dan mengaplikasikannya untuk memecahkan permasalahan yang ditemukan dalam kehidupan sehari-hari; (3) konsultan pembelajaran, guru masa depan adalah guru-guru yang ahli dalam bidang-bidang mereka. Mereka memegang peranan yang sangat penting sebagai konsultan Jurnal Ilmu Sosial dan Pendidikan pembelajaran yang mendiagnosa berbagai masalah yang dihadapi siswa, serta menyediakan metode-metode yang membantu aktivitas belajar. Untuk peran ini guru perlu pengetahuan dan keterampilan untuk mencocokkan, menemukan, mengembangkan dan mengaplikasikan berbagai metodologi pembelajaran. Secara khusus, dalam menggunakan berbagai sumber pembelajaran digital, guru perlu menjadi literat dalam dunia digital, memiliki kemampuan untuk mencari, mengevaluasi, memperbaiki, memproses dan menggunakan informasi digital. Beberapa hal yang termasuk keberaksaraan digital antara lain kemampuan berbagi hasil pembelajaran dengan orang lain, serta membangun dan mempertahankan berbagai komunitas cyber. Keberaksaraan digital adalah syarat mutlak dalam pengembangan dunia digital dan vitalisasi kehidupan digital, serta juga merupakan salah satu kemampuan mendasar untuk membantu generasi muda masa depan dalam berinteraksi di ruang cyber. Guru dengan keberaksaraan digital memegang peran yang sangat penting sebagai konsultan pembelajaran untuk membantu siswa dalam pemerolehan informasi, navigasi informasi dan berbagi informasi.

Sanjaya (2006), peran guru dalam pembelajaran era digital ada tujuh yakni: (1) guru sebagai sumber belajar; peran guru sebagai sumber belajar berkaitan dengan kemampuan guru dalam menguasai materi pelajaran. Sehingga ketika siswa bertanya, dengan sigap dan cepat tanggap, guru akan dapat langsung menjawabnya dengan bahasa yang mudah dimengerti oleh siswanya; (2) guru sebagai fasilitator; peran guru dalam memberikan pelayanan kepada siswa untuk dapat memudahkan siswa menerima materi pelajaran. Sehingga pembelajaran menjadi efektif dan efisien; (3) guru sebagai pengelola; dalam proses pembelajaran, guru berperan untuk memegang kendali penuh atas iklim dalam suasana pembelajaran. 
Diibaratkan seperti seorang nahkoda yang memegang setir kemudi kapal, yang membawa jalannya kapal ke jalan yang aman dan nyaman. Guru haruslah menciptakan suasana kelas yang nyaman dan kondusif. Sehingga siswa dapat menerima pembelajaran dengan nyaman; (4) guru sebagai demonstrator; berperan sebagai demonstrator maksudnya disini bukanlah turun ke jalan untuk berdemo. Namun yang dimaksudkan disini adalah guru itu sebagai sosok yang berperan untuk menunjukkan sikap-sikap yang akan menginspirasi siswa untuk melakukan hal yang sama, bahkan lebih baik; (5) guru sebagai pembimbing; perannya sebagai seorang pembimbing, guru diminta untuk dapat mengarahkan kepada siswa untuk menjadi seperti yang diinginkannya. Namun tentunya, haruslah guru membimbing dan mengarahkan untuk dapat mencapai cita-cita dan impian siswa tersebut; (6) guru sebagai motivator; proses pembelajaran akan berhasil jika siswa memiliki motivasi didalam dirinya. Oleh karena itu, guru juga berperan penting dalam menumbuhkan motivasi dan semangat dalam diri siswa untuk belajar; (7) guru sebagai elevator; setelah melakukan proses pembelajaran, guru haruslah mengevaluasi semua hasil yang telah dilakukan selama.

\section{KESIMPUALAN}

Dalam komunitas digital global hendaknya paling tidak dilakukan 3 (tiga) pembelajaran, yaitu: (a) pembelajaran yang memusatkan pada konstruksi pencarian dan penemuan, (b) pembelajaran yang menekankan pada kreativitas dan inisiatif, dan (c) pembelajaran yang menekankan pada interaksi dan kerjasama

Peran guru dalam pembelajaran era digital ada tujuh yakni: (a) guru sebagai sumber belajar; peran guru sebagai sumber belajar berkaitan dengan kemampuan guru dalam menguasai materi pelajaran. (b) guru sebagai fasilitator; peran guru sebagai fasilitator dalam memberikan pelayanan kepada siswa untuk dapat memudahkan siswa Jurnal Ilmu Sosial dan Pendidikan menerima materi pelajaran. (c) guru sebagai pengelola; dalam proses pembelajaran, guru berperan untuk memegang kendali penuh atas iklim dalam suasana pembelajaran; (d) guru sebagai demonstrator; berperan sebagai demonstrator maksudnya disini bukanlah turun ke jalan untuk berdemo. Guru itu sebagai sosok yang berperan untuk menunjukkan sikap-sikap yang akan menginspirasi siswa untuk melakukan hal yang sama, bahkan lebih baik; (e) guru sebagai pembimbing; perannya sebagai seorang pembimbing, guru diminta untuk dapat mengarahkan kepada siswa untuk menjadi seperti yang diinginkannya; (f) guru sebagai motivator; proses pembelajaran akan berhasil jika siswa memiliki motivasi didalam dirinya; (g) guru sebagai elevator; guru haruslah mengevaluasi semua hasil yang telah dilakukan selama proses pembelajaran.

Tantangan guru di era digital; guru sampai sekarang masih banyak memakai produk 80-an, sementara muridnya sudah memakai produk kontemporer. Akibatnya, para murid berbeda secara radikal dengan para guru, karena banyak terjadi ketidaknyambungan di sana-sini. Kita tahu bahwa murid sekarang tidak lagi cocok dengan sistem pendidikan abad 20. Namun, praksis di lapangan para guru masih tidak memahami hal ini. Banyak guru kita yang lambat mengejar laju modernisasi pendidikan. Yang terjadi kemudian adalah murid sudah mampu menerima informasi secara cepat dari berbagai sumber multimedia, sementara banyak guru acapkali memberikan informasi dengan lambat dan dari sumber-sumber terbatas.

Strategi mengatasi tantangan; sistem pendidikan yang masih terjebak pada otoritas struktural-birokratis harus segera dibenahi. Daya kreasi dan inovasi seorang guru harus segera dimunculkan. Guru era digital tidak boleh mengikuti kurikulum yang baku dan kaku. Sebab, kenyataan dari banyaknya sistem pembelajaran yang berlangsung, guru masih berkutat pada apa-apa 
yang tengah dicetuskan oleh dan Kemampuan"Prisma pemerintah, di mana ketika guru mengajar No.2.Th.V.Jakarta. LP3S.

hanya terpaku pada target kurikulum yang kaku dan mekanistis. Dengan demikian, banyak kita temukan tipe-tipe guru kurikulum. Yakni guru yang melihat tolok ukur keberhasilan dipusatkan pada angka kuantitatif yang diperoleh dalam evaluasi saja. Jika guru belum dapat sepenuhnya masuk di era digital, mereka dapat menjadi jembatan revolusi. Yakni, dengan cara menjadikan dirinya sebagai motivator, yang menggerakkan anak didik pada sumber belajar yang dapat diakses. Sebagai dinamisator, yakni memantau anak didik agar mengembangkan kreativitas dan imajinasinya. Sebagai evaluator dan justifikator, yaitu dapat menilai dan memberi catatan, tambahan, perbendaharaan dan sebagainya terhadap temuan siswa.

\section{DAFTAR PUSTAKA}

Bastian, Aulia Reza. (2002). Reformasi Pendidikan: Langkah-Langkah Pembaharuan dan Pemberdayaan Pendidikan Dalam rangka Desentralisasi Sistem Pendidikan Indonesia

Bennett, N. (1993). Knowledge Bases for Learning To Teach. Dalam N. Bannett \& C.

Carre (Eds.), Learning to teach (h. 1-17). New York: Routledge.

Buchori, Mochtar. (1995). Transformasi Pendidikan. Pustaka Sinar Harapan.

Depdikbud. (2003). Seri Kebijaksanaan Depdikbud: Sistem Pengadaan,

Pemanfaatan dan Pembinaan Guru

Geddis, A. N. Et. Al. (1993). Transforming Content Knowledge: Learning to Teach about Isotopes. Science Educational, 77, 6, 575-591.

Karim dan Saleh Sugiyanto. (2006). Menampung Anak Usia Sekolah: Antara Target 